\title{
STUDI KOMPARASI METODOLOGI PENETAPAN HUKUM ISLAM LEMBAGA - LEMBAGA FATWA DI INDONESIA
}

\author{
ZUHRONI \\ BAGIAN AGAMA UNIVERSITAS YARSI \\ Email : zuhroni@gmail.com \\ zuhroni@yarsi.ac.id
}

\begin{abstract}
This study is to see how Indonesian Ulemas, particularly those involved in authorized fatwa issuer institutions in Indonesia, respond to contemporary issues. The main object of this study is methodologies of establishing Islamic laws among national fatwa authorities in Indonesia. In Indonesia, there are four fatwa issuer institutions - Lajnah Bahtsul Masail Diniyyah NU, Majlis Tarjih Muhammadiyah, Komisi Fatwa MUI, and Dewan Hisbah PERSIS-actively responding to contemporary issues. A literature study suggests that Indonesian ulemas pay significant attention to issues related to science and technology. When formulating a fatwa, they apply three methods: referring to fikih books (Islamic jurisprudential sources), commonly done by Bahtsul Masail; Majlis Tarjih and Dewan Hisbah, commonly done by mujtahids, especially when facing deadlock after having deduced Qur'anic verses and alhadith; and flexible method, usually academically formulated, commonly done by MUI.
\end{abstract}

Keywords : Fatwa (juristic ruling by fukaha), Ijtihad jama'i (collective ijtihads), Istinbahth al-hukm (Law establishment)

\begin{abstract}
Abstrak
Studi ini bertujuan untuk mengetahui bagaimana Ulama Indonesia, khusus yang tergabung dalam lembaga - lembaga fatwa yang ada di Indonesia, merespon isu isu kontempoter. Obyek utama studi adalah metodologi penetapan hukum Islam dari organisasi keulamaan di Indonesia yang bersifat nasional di level pusat. Di Indonesia terdapat empat lembaga fatwa yang aktif merespon isu-isu kontemporer, yaitu Lajnah Bahtsul Masail Diniyyah NU, Majlis Tarjih Muhammadiyah, Komisi Fatwa MUI, dan Dewan Hisbah PERSIS. Dari hasil kajian literatur, menunjukkan bahwa berbagai hal yang terkait dengan perkembangan IPTEK mendapatkan perhatian cukup besar dari ulama Indonesia. Dalam menetapkan hukum, terdapat tiga tipologi metode. Pertama, menentukannya berdasarkan kitab - kitab fikih, dilakukan oleh Bahtsul Masail. Tipe kedua, Majlis Tarjih dan Dewan Hisbah, pada kasus yang tidak dapat diselesaikan dengan Alquran dan Sunnah, penyelesaiannya tidak ada pilihan lain maka menggunakan metode yang disusun para mujtahidin. Tipe ketiga, bersifat fleksibel, dapat menggunakan metode yang ada sebagaimana dirumuskan secara akademis, dilakukan oleh MUI.
\end{abstract}


Kata Kunci : Fatwa, Ijtihad jama'i, Istinbahth al-hukm

\section{Pendahuluan}

Seiring dengan kemajuan IPTEK, untuk meresponnya para Ulama di Indonesia telah membentuk lembaga-lembaga fatwa yang bertugas menentukan hukum Islam secara kolektif, berijtihad jamā'i. Definisi ijtihad kolektif (ijtihād jamá'i) adalah sebuah upaya optimal dari mayoritas ahli fikih untuk sampai pada hipotesa terhadap hukum syariat dengan cara menyimpulkan dan telah mencapai kesepakatan mereka, atau mayoritas dari mereka setelah mengadakan diskusi untuk menentukan hukum. Menurut 'Ali Hasaballāh yang membedakan ijtihād fardi dengan Ijtihād jamā'i. secara praktis yang terakhir dilakukan oleh para ahli dari berbagai disiplin ilmu. ${ }^{1}$

Secara teoritis produk hukum dari hasil ijtihād jamā'i dipandang lebih mendekati kepada kebenaran dan lebih kuat daripada hasil ijtihäd fardi yang seringkali melihat 'sesuatu' hanya dari satu sudut pandang saja. Tentang urgensi dan lingkup ijtihād jamā'i dewasa ini, menurut Harun Nasution, yang lebih dibutuhkan adalah ijtihad kolektif berskala nasional. Sebab, masalah keagamaan yang muncul di zaman kemajuan ilmu pengetahuan dan teknologi ini tidak sama, juga karena beragamnya penafsiran dan pengamalan agama di negara-negara Islam. $^{2}$

Ada empat lembaga fatwa di Indonesia yang cukup aktif merespon isu-isu kontemporer, yaitu: Lajnah Bahtsul Masail Diniyyah NU., Majlis Tarjih Muhammadiyah, Komisi Fatwa MUI, dan Dewan Hisbah PERSIS, merupakan lembaga-lembaga yang dianggap mempunyai otoritas berfatwa (al-Ijāzat li alIftā). Ketentuan - ketentuan hukum yang ditetapkan oleh empat lembaga tersebut berbentuk fatwa yang bersifat dīwāni atau ahk kām taklīfiyyat, ditetapkan dalam Muktamar, Munas, sidang khusus, atau yang sejenis.

\footnotetext{
${ }^{1}$ Lihat 'Abdul Majīd al-Syarafi, terj. Syamsuddin T., Ijtihad Kolektif, (Jakarta: Pustaka Kautsar, 2002), hal. 10, 12. Lihat juga 'Ali Hasaballāh, Ushūl al-Tasyri' al-Islāmi, (Mesir: Dār al-Ma'ārif, 1976), hal. 107108.

${ }^{2}$ Harun Nasution, "Ijtihad Sumber Ketiga Ajaran Islam" dalam Jalaluddin Rahmat (ed.), Ijtihad dalam Sorotan, (Bandung: Mizan, 1996), h. 115.
} 
Kekhasan lembaga - lembaga ijtihad kolektif dalam menentukan hukum, dilakukan oleh para ulama secara bersama-sama. Untuk akurasi fatwa, dalam kasus - kasus khusus, biasanya terlebih dahulu mengundang atau meminta penjelasan dari pakar bidang terkait meski tidak termasuk dalam kategori term alim - ulama. Cara ini diyakini akan menghasilkan keputusan hukum lebih akurat, obyektif, dan lebih unggul dibandingkan dengan ijtihad fardi (ijtihad individual).

\section{A. Lajnah Bahtsul Masail NU}

Lajnah Bahtsul Masail Diniyyah secara bahasa berarti institusi pembahasan masalah-masalah keagamaan aktual, merupakan sebuah forum untuk memutuskan suatu hukum dalam NU. Secara historis, pada mulanya forum Bahtsul Masail sebagai sebuah kegiatan sudah ada sebelum NU berdiri, tradisi diskusi di kalangan pesantren yang melibatkan kiyai dan santri yang hasilnya diterbitkan dalam buletin LINO (Lailatul Ijtima' Nahdlatul Oelama). Buletin LINO, juga menjadi ajang diskusi interaktif jarak jauh antar para ulama, seorang kiyai menulis ditanggapi kiyai lain, dan begitu seterusnya. ${ }^{3}$ Bahts al-masāil pertama dilaksanakan pada tahun 1926, beberapa bulan setelah berdirinya NU. Sebagai forum khusus, keberadaannya hampir bersamaan dengan keberadaan NU, sejak Muktamar I, tetapi sebagai institusi resmi ada pada Muktamar XXVIII di Yogyakarta pada tahun 1989.

Sejak Muktamar XXVIII (Yogyakarta, tahun 1989), seiring dengan dinamika pemikiran dalam internal NU, forum pembahasan dalam Bahtsul Masail dibagi dua, Bahtsul Masail Diniyyah Waqi'iyyah dan Bahtsul Masail Diniyyah Maudlu'iyyah. Bahtsul Masail Diniyyah Waqi'iyyah merupakan kelanjutan dari Bahtsul Masail sejak berdiri, dengan ciri pola jawaban diberikan secara singkat, tegas, disertai argumen tekstual dari kitab. Bahtsul Masail Diniyyah Maudlu'iyyah bertugas merespon problem aktual yang dihadapi oleh bangsa dan kaum muslimin secara keseluruhan, pembahasan masalah secara konseptual. Pola jawaban

\footnotetext{
${ }^{3}$ M. Imdadun Rahmat (Ed.), Kritik Nalar Fiqih NU., Transformasi Paradigma Bahtsul Masail, (Jakarta: Lakpesdam, 2002), hal. xiii. Imam Ghazali Said dan A. Ma'ruf Asrori, Solusi Problematika Aktual Hukum Islam, Keputusan Muktamar, Munas, dan Konbes Nahdlatul Ulama (1926 M.-1999 M.), (Surabaya: Lajnah Ta'lif Wan Nasyr (LTN) Jawa Timur Bekerja Sama dengan Penerbit Diantara Surabaya, 2004), hal.ix.
} 
diberikan secara lebih detail dan terlihat sangat liberal. ${ }^{4}$ Forum ini dikoordinir oleh lembaga Syuriyah (legislatif) NU. Biasanya, keanggotaannya berasal dari Syuriah dan ulama - ulama NU yang berada di luar struktur organisasi, termasuk para pengasuh pesantren.

Tugas Bahtsul Masail, berdasarkan ART NU, adalah 'menghimpun, membahas, dan memecahkan masalah-masalah yang mauqūf dan waqi'ah yang harus segera mendapat kepastian hukum'. Farum ini bertugas merespon masalah waq'iyyat (aktual) yang sedang terjadi di masyarakat yang diajukan kepada Syuriah. Terhadap masalah yang mauqū $f$ (kemacetan, tidak terjawab) dilakukan pembahasan ulang di tingkat yang lebih tinggi hingga akhirnya ke tingkat nasional. $^{5}$

Proses pemilihan dan penentuan isu yang diangkat, biasanya berasal dari masyarakat yang diajukan kepada Majlis Syuriah NU tingkat cabang (Kabupaten, kota, atau Pesantren Besar) guna menyelenggarakan sidang Bahts al-Masāil, hasilnya diserahkan kepada Majlis Syuriah NU tingkat Wilayah (Propinsi) untuk diadakan sidang Bahtsul Masail, selanjutnya dibahas masalah-masalah yang dianggap urgen bagi kehidupan umat. Permasalahan yang belum tuntas atau masih diperselisihkan, diserahkan kepada Majlis Syuriah PBNU untuk diinventarisasi dan diseleksi berdasarkan prioritas pembahasan, dan kadang-kadang ditambah permasalahan yang diajukan oleh PBNU sendiri. Daftar masalah tersebut kemudian diedarkan kepada para ulama dan cendekiawan NU yang ditunjuk sebagai anggota Lajnah Bahtsul Masail untuk dipelajari dan disiapkan jawabannya. ${ }^{6}$ Jawaban dicarikan di berbagai literatur kitab-kitab klasik, modern, atau majalah yang ditulis oleh ulama yang dinilai dan diakui kredibilitas keilmuannya. Setelah mendengar argumen dari peserta Bahtsul Masail dengan landasan teks rujukan dalam sidang komisi, pimpinan membuat kesimpulan,

\footnotetext{
${ }^{4}$ H. Aziz Masyhuri, Masalah Keagamaan, (Surabaya: Dinamika Press, 1997), hal. 362. Lihat pula Imam Ghazali Said 'Dokementasi dan Dinamika Pemikiran Ulama Bermazhab' dalam Imam Ghazali Said dan A. Ma'ruf Asrori (peny.), Ibid., hal. xx

${ }^{5}$ Lihat Sahal Mahfudh 'Bahtsul Masail dan Intinbath Hukum NU, Sebuah Catatan Pendek'. Sebuah artikel pendek dimuat dalam 2 buku, dan website. M. Imdadun Rahmat (Ed.), op. cit., hal. xii. dalam Imam Ghazali Said dan A. Ma'ruf Asrori, Ibid., hal.viii.

${ }^{6}$ Ahmad Zahro, Lajnah Bahtsul Masail 1926-1999: Tradisi Intelektual NU, (Yogyakarta: LkiS, 2002).., hal. $267-268$
} 
kemudian ditawarkan kepada peserta untuk ditetapkan hukumnya secara kolektif, selanjutnya dirumuskan oleh tim perumus, dan hasilnya dibawa ke sidang pleno.

Sejak dibentuk di Surabaya pada tahun 1926, Bahtsul Masail telah mengadakan banyak pertemuan berskala nasional dalam bentuk Muktamar, Konbes, Munas, dan rapat Dewan Partai. Sidang selalu dibarengkan dengan kegiatan NU yang berskala nasional tersebut. Sekurangnya, berdasarkan data dalam himpunan putusan Bahtsul Masail, telah membahas 437 masalah keagamaan. ${ }^{7}$ Berdasarkan hitungan yang pernah dilakukan, sampai tahun 1997 sekurangnya ada 47 masalah dari total 422 masalah yang telah dikeluarkan oleh Bahtsul Masail. Rincian prosentasi dan perbandingannya, menurut hitungan yang dilakukan oleh Imam Yahya, persoalan kesehatan dan kedokteran 13,3 \%, politik 2,9 \%, ekonomi 11,6 \%, sosial kemasyarakatan sekitar 5,5\%, advokasi 2,9 \%, pertanian dan perkebunan $3,13 \%$, dan masalah keagamaan $62,16 \%{ }^{8}$

Dalam menetapkan hukum, Bahtsul Masail tidak langsung mengutip dari nash Al - Quran dan Hadis, tetapi men-tahbīq-kannya dengan nash-nash dalam kitab, jika tidak ditemukan maka dilakukan ilhāa al-Masāil binazhāirihā secara jamā'i. Alasannya, karena mereka menyadari sulit dilakukan, sadar atas keterbatasan untuk terpenuhinya persyaratan menjadi mujtahid. ${ }^{9}$ Di samping soal kompetensi dan otoritas berijtihad, juga tidak terlepas dari kebiasaan di pesantren

\footnotetext{
${ }^{7}$ Berdasarkan penomeran masalah dalam Himpunan Keputusan Bahtsul Masail susunan A. Aziz Masyhuri, buku terakhir, terbit bulan Nop 2004, berjumlah 433 masalah (dengan mengabaikan kerancuan sistem penomerannya) ditambah dengan 4 masalah dalam Muktamar XXXI. Lihat A. Aziz Masyhuri, Masalah Keagamaan, Hasil Muktamar dan Munas Ulama Nahdlatul Ulama Kesatu / 1926 s/d Ketigapuluh / 2000, (Depok: Qultum Media, 2004). Berdasarkan isinya, judul ini tidak tepat, bukan 'Ketigapuluh / 2000', jika yang dimaksud Muktamar ke-30, mestinya tahun 1999. Atau jika yang dimaksud putusan terakhir, mestinya Munas / 2002. Jumlah tersebut di atas hanya berdasarkan pada dokumen yang sudah ditemukan saja, sebab, sampai kini belum seluruh dokumen keputusan Bahtsul Masail telah ditemukan, baik yang dihimpun oleh A. Aziz Masyhuri maupun H. Imam Ghazali Said dan A. Ma'ruf Asrori. Ada 5 hasil keputusan Muktamar Bahtsul Masail belum ditemukan, yaitu XVII (1947), XVIII (1950), XIX (1956), XXI (1959), dan XXIV (1967).

${ }^{8}$ Angka-angka ini berdasarkan perhitungan Imam Yahya, jika dilihat pada materi masalah, pengkelompokan tersebut tampak tidak akurat, misalnya, pada tabel tertera masalah yang berhubungan dengan kedokteran dan kesehatan berjumlah sekian masalah, setelah dilihat ternyata tidak jelas, bukan masalah kedokteran tetapi dimasukkan dalam masalah kedokteran. Lihat Imam Yahya "Fiqih Sosial NU: Dari Tradisionalis Menuju Kontekstualis" dalam M. Imdadun Rahmat (Ed.), op. cit., hal. 11-12.

${ }^{9}$ Sahal Mahfudz "Bahtsul Masail dan Istinbath Hukum NU: Sebuah Catatan Pendek" dalam Imam Ghazali Said dan A. Ma'ruf Asrori, op. cit., hal. xi.
} 
yang sangat menjunjung tinggi silsilah intelekstual dalam tradisi mengambil dan mengamalkan suatu ilmu, harus jelas kualitas keilmuan seseorang yang diikuti. ${ }^{10}$

Konsistensi terhadap pendirian ini terbukti dalam dokumen keputusan hukum Bahtsul Masail, sangat sedikit yang merujuk langsung kepada Al - Quran maupun Hadis, dari 427 masalah yang difatwakan hingga tahun 1999, tercatat, hanya ada empat jawaban merujuk langsung pada ayat Al - Quran dan Hadis tanpa menjelaskan proses istidlal-nya, dan 14 jawaban merujuknya melalui kitab - kitab kuning. ${ }^{11}$

Bahtsul Masail berkomitmen mengikuti pola bermazhab 'ala ahl al-Sunnat wa al-Jamā'at, bahkan masalah pertama yang ditetapkan pada Muktamar I (1926 M.) menegaskan 'wajib bagi umat Islam mengikuti salah satu dari empat mazhab'. ${ }^{12}$ Secara teoritis, Bahtsul Masail akan konsisten menjawab setiap masalah waqi'iyyat (kontemporer) dengan merujuk pada kitab-kitab empat mazhab, terutama dari Mazhab Syāfi'i. Dari hasil penelitian Ahmad Zahro membuktikan, frekwensi pengambilan sumber dari kitab sebanyak 925 kali, 755 kali $(91,5 \%)$ bersumber dari kitab-kitab Syāfi'iyyat. Kitab-kitab selain Mazhab Syāfi'i sebanyak 70 kali (8,5 \%) yang terdiri atas Mazhab Maliki 14 kali (1,8\%), Mazhab Hanafi 6 kali (0,7 \%), dan Mazhab Hanbali hanya 2 kali (0,2 \%). Dari buku yang dijadikan rujukan berjumlah 153 judul, 4 judul (2.6\%) bermazhab

\footnotetext{
${ }^{10}$ Lihat M. Masyhur Amin, NU \& Ijtihad Politik Kenegaraannya, (Yogyakarta: Al-Amin Press, 1996), hal.94.

${ }^{11}$ Imam Ghazali Said dan A. Ma'ruf Asrori, op. cit., hal. xxxvii-xxxviii. Empat fatwa tersebut adalah NM 206 dan 251 (Muktamar ke-12, 1937), jawaban tentang membaca Manaqib Syeh Abdul Qadir, mengutip langsung dari Hadis: "Siapa yang beriman kepada Allah, supaya menghormati tamu", jawaban juga disertai dengan kutipan dari teks kitab. NM. 251, jawaban tentang lelaki diberi nafkah oleh isteri dengan Q.s. al-Nisā' (4):4. NM 259 (Muktamar ke-15, 1940), jawaban tentang tidak mau membeli di toko orang Islam, dengan merujuk Q.s. al-Māidah (5):2 disertakan pula kutipan dari teks kitab. NM. 412, barangkali yang dimaksud adalah NM. 410, sebab NM. 412, jawaban tentang mencetak dan menerbitkan karya tulis orang lain ditetapkan berdasarkan kutipan dari teks kitab, sedangkan NM. 410 jawaban tentang Bai'ul Inah, di samping mengutip teks kitab juga langsung dari Hadis. Jika diteliti lebih cermat fatwa yang ada, sebagaimana yang tercatat dalam 2 kumpulan fatwa di atas, sebenarnya masih ada yang lain, di antaranya NM. 19 (Muktamar ke-1, 1926), tentang sedekah kepada mayit, NM 92 (Muktamar ke-5, 1930), tentang minum bir. NM 427 tentang anggota DPR/MPR beragama Non-muslim berdasarkan Q.s. al-Nisāe(4):141. Jawaban tentang masalah masuk PNS dengan membayar sejumlah uang berdasarkan Q.s. al-Baqarat (2):188, Hadis, dan teks kitab. Demikian juga fatwa tentang hukuman bagi produsen dan pemasok psichotropika dan narkotika, serta tes DNA.

${ }^{12}$ Lihat masalah no 1, A. Aziz Masyhuri, Masalah Keagamaan Hasil Muktamar dan Munas Ulama Nahdlatul Ulama Kesatu 1926 s/d Keduapuluh Sembilan 1994, hal. 2.
} 
Hanafi, 10 judul (6,5 \%) bermazhab Māliki, 109 judul (71,2 \%) bermazhab Syāfi'i, 2 judul (1,3 \%) bermazhab ㅂanbali, dan 28 judul $(18,4 \%)$ umum. $^{13}$

Mengingat buku-buku dalam Mazhab Syāfi'i sangat banyak, pada Muktamar I diputuskan skala prioritas pendapat yang dipergunakan. ${ }^{14}$ Demikian fanatis dan ekstrimnya pola ini, pada Muktamar XI (1935 M.) dipertegas lagi saat menjawab pertanyaan tentang berdalil langsung dari Al - Quran dan Hadis, tidak dari kitabkitab fiqih, ditegaskan bahwa 'Sesungguhnya demikian itu tidak boleh, dan yang berbuat demikian itu tidak benar juga sesat dan menyesatkan'. ${ }^{15}$ Namun demikian, realitas data dalam himpunan keputusan hukum Bahtsul Masail sekurangnya ada 16 masalah, atau sekitar 3,75\% ditetapkan tanpa dirujuk ma'khadz-nya. ${ }^{16}$

Dalam hal ditemukan banyak pendapat, Bahtsul Masail memilih pendapat yang terkuat. Keputusan - keputusannya merupakan kesepakatan peserta muktamar atau Munas, kadang keputusan itu tidak hanya satu pendapat, tetapi dibiarkan tetap dalam perbedaan, sepakat dalam khiläf, seperti dalam keputusan tentang status bunga bank yang dalam keputusan Muktamar NU hingga tahun 1971 di Surabaya mengambil sikap hukumnya halal, haram, dan subhat, ${ }^{17}$ bahkan dipertegas lagi dalam Munas NU di Lampung pada tahun $1992 .{ }^{18}$

Agar terjadi standarisasi dalam penggunaan kitab rujukan, Bahtsul Masail menetapkan al-Kutub al-Mu'tabarat. Nampaknya, langkah ini diyakini dapat menghindari inkonsistensi. Sebab, jika tidak ada standar baku yang digunakan, tidak jelas kriterianya, dalam aplikasinya secara alamiah akan terjadi pergeseran, tidak mengikuti pola yang telah digariskan. Namun demikian, dalam realitas kadang-kadang juga mengutip pendapat sejumlah majalah, kitab-kitab yang tidak bermazhab tertentu, dan kitab-kitab baru.

\footnotetext{
${ }^{13}$ Lihat Ahmad Zahro, op. cit., hal. 160.

${ }^{14}$ Pendapat yang boleh dijadikan rujukan dalam berfatwa secara hirarkis prioritas, lihat A. Aziz Masyhuri, Masalah Keagamaan Hasil Muktamar dan Munas Ulama Nahdlatul Ulama Kesatu 1926 s/d Keduapuluh Sembilan 1994, hal. 3. Juga, Imam Ghazali Said dan A. Ma'ruf Asrori, op. cit., hal. 3.

${ }^{15}$ A. Aziz Masyhuri, Ibid., hal. 137.

${ }^{16}$ Daftar masalah-masalah yang tidak menyertakan $m a^{\prime}$ khadz-nya (sumber pengam-bilannya), lihat Imam Ghazali Said dan A. Ma'ruf Asrori, op. cit., hal. xxxv-xxxvi.

${ }^{17}$ A. Aziz Masyhuri, op. cit., hal. 250.

${ }^{18}$ Lihat PBNU., Keputusan Munas Alim Ulama \& Konbes Nahdlatul Ulama di Ban-dar Lampung 16-20 Rajab, 21-25 Januari 1992, hal. 12-20.
} 
Ada perbedaan dalam sistem pengambilan keputusan hukum antara sebelum dan pasca Munas Bahtsul Masail di Bandar Lampung 1992. Sistem dan prosedur pengambilan atau penetapan hukum sejak Munas 1992 telah dirumuskan melalui 4 ketentuan umum:

1. Dalam kasus ketika jawaban bisa dicukupi oleh ibarat kitab dan di sana terdapat hanya satu qaul / wajah, maka dipakailah qaul / wajah sebagaimana diterangkan dalam 'ibarat tersebut.

2. Dalam kasus ketika jawaban bisa dicukupi oleh 'ibarat kitab dan di sana terdapat lebih dari satu qaul/wajah, maka dilakukan taqrīr jamā'i untuk memilih satu qaul / wajah.

3. Dalam kasus tidak ada qaul / wajah sama sekali yang memberikan penyelesaian, maka dilakukan prosedur Ilhāaul Masāil binazhāirihā secara jamā'i oleh para ahlinya.

4. Dalam kasus tidak ada qaul / wajah sama sekali dan tidak mungkin dilakukan

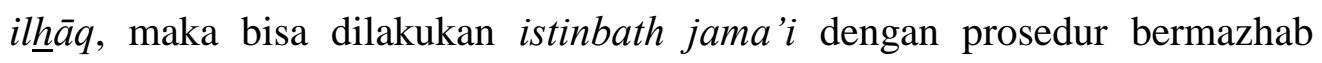
secara manhaji oleh para ahlinya. ${ }^{19}$

Aplikasi 4 ketentuan di atas dalam hal banyak pendapat, pemilihan dilakukan dengan mengambil pendapat yang dinilai lebih maslahat dan atau yang lebih kuat. $^{20}$

Dilihat dari segi format susunan, keputusan-keputusan hukum Bahtsul Masail disusun tidak seperti format surat keputusan modern, lebih berbentuk soaljawab, langsung pada pertanyaan dan jawabannya yang merupakan keputusan dari Bahtsul Masail, disertakan dasar / nash yang dijadikan sebagai dalil, disebutkan nama judul kitab, jilid, halaman, dan kutipan teks kitab yang dimaksud. Sejak Muktamar ke-28 di Yogyakarta, 25-28 Nopember 1989, keputusan-keputusan disusun dengan format yang masih sama, namun dikuatkan lagi dengan surat pengesahan oleh pimpinan sidang pleno, ketua dan sekretaris, dengan mengikuti

\footnotetext{
${ }^{19}$ Lihat PBNU, Keputusan Munas Alim Ulama \& Konbes Nahdlatul Ulama di Bandar Lampung 16-20 Rajab, 21-25 Januari 1992, hal. 5-6. PBNU, Hasil-hasil Muktamar XXXI Nahdlatul Ulama, (Jakarta: PB NU, 2005), hal. 5-7.

${ }^{20}$ Ibid., hal. 7.
} 
format surat keputusan modern, seperti disertakan kalimat memperhatikan, mendengar, mengesahkan, memutuskan, atau menetapkan.

\section{Majlis Tarjih Muhammadiyah}

Muhammadiyah berdiri pada tahun 1912 yang mewadahi beberapa departemen, di antaranya adalah Majlis Tasyri' dengan nama Majlis Tarjih yang dibentuk pada tahun 1928. Secara bahasa, Majlis Tarjih berarti majlis pencari pendapat terkuat. Majlis Tarjih merupakan sebuah lembaga di bawah PP. Muhammadiyah, dan Lajnah Tarjih adalah sidang yang membicarakan masalahmasalah yang akan ditarjih. ${ }^{21}$

Latar belakang alasan pendirian Majlis Tarjih diumumkan pada tahun 1935 oleh PP. Muhammadiyah, berangkat dari kenyataan adanya banyak pendapat dalam masalah hukum Islam di kalangan ulama yang ternyata mewariskan percekcokan dan perselisihan umat. Tugas utamanya, adalah menimbang dan memilih pendapat manakah yang dianggap kuat dan berdalil benar dari Al Quran dan Hadis. ${ }^{22}$ Secara khusus rumusan tugas Majlis Tarjih adalah menyampaikan fatwa untuk dijalankan kepada umat, anggota dan keluarga Muhammadiyah. Juga, menyalurkan perbedaan pendapat/faham dalam bidang keagamaan ke arah yang lebih maslahah. ${ }^{23}$

Tugas Majlis Tarjih berdasarkan keputusan PP. Muhammadiyah, adalah:

1. Menyelidiki dan memahami ilmu agama Islam untuk memperoleh kemurniannya.

2. Menyusun tuntunan aqidah, akhlaq, ibadah dan, muamalah dunyawiah.

3. Memberi fatwa dan nasihat, baik atas permintaan maupun tarjih sendiri memandang perlu.

4. Menyalurkan perbedaan pendapat / faham dalam bidang keagamaan ke arah yang lebih maslahat.

\footnotetext{
${ }^{21}$ Rifyal Ka'bah, Hukum Islam di Indonesia, Perspektif Muhammadiyah dan NU, (Jakarta: Universitas YARSI Jakarta, 1999), hal. 95.

${ }^{22}$ PP. Muhammadiyah, Himpunan Putusan Majlis Tarjih Muhammadiyah, (tt.: PP. Majlis Tarjih Muhammadiyah, tth.), hal. 371 .

${ }^{23}$ Lihat pasal 3, butir b dan e dalam PP. Muhammadiyah, Himpunan Qaidah / Peraturan Majlis Badan Lembaga Muhammadiyah, hal. 2.
} 
5. Mempertinggi mutu ulama.

6. Hal-hal lain dalam bidang keagamaan yang diserahkan oleh Pimpinan Persyarikatan. $^{24}$

Dari poin-poin di atas, bahwa Majlis Tarjih berfungsi sebagai majlis tasyri', bertugas menetapkan hukum agama, sama dengan lembaga-lembaga fatwa yang lain, menetapkan hukum Islam secara jamä'i. Sebagai forum resmi, Majlis Tarjih sebagai salah satu pionir di dunia Islam dalam hal ijtihād jamā'i di abad modern, sidang I diadakan pada tahun $1929 .^{25}$

Sidang Majlis Tarjih diadakan ada kalanya bersamaan dengan Muktamar Muhammadiyah sesuai dengan keputusan pimpinan organisasi yang kemudian dikenal dengan muktamar khususi. Dokumen fatwa yang telah ditetapkan hukumnya dalam muktamar dan telah di-tanfidz-kan oleh PP. Muhammadiyah dihimpun dalam bentuk Himpunan Putusan Tarjih Muhammadiyah, di antaranya masih berbentuk stensilan khusus untuk kalangan sendiri dan sebagian di antaranya telah diterbitkan dalam bentuk buku untuk umum. ${ }^{26}$ Dokumen untuk umum tersebut disusun berdasarkan topik, bukan pada urutan historis urutan dikeluarkannya, hal ini menyulitkan untuk mengetahui kapan dikeluarkan.

Ada pula fatwa yang dikeluarkan oleh Tim PP. Muhammadiyah Majlis Tarjih yang merupakan jawaban atas pertanyaan pembaca Suara Muhammadiyah oleh tim ahli yang dibantu anggota Majlis Tarjih sejak tahun $1986 .{ }^{27}$ Forum ini, diadakan dalam rangka mengisi kelambanan responnya yang bersidang melalui muktamar yang jika konsisten dengan ketentuan yang ada mestinya berlangsung setiap tiga tahun sekali, meski dalam pelaksanaannya tidak selalu demikian. Misalnya, Muktamar ke-21 diadakan di Klaten, tahun 1980, muktamar ke-22 baru dilaksanakan di Malang, tahun 1989, berjarak sembilan tahun. Dari segi legalitas,

\footnotetext{
${ }^{24}$ PP. Muhammadiyah Majlis Tarjih, Qaidah Lajnah Muhammadiyah, (Yogyakarta: PP. Muhammadiyah Majlis Tarjih, 1971), hal. 2.

${ }^{25}$ Rifyal Ka'bah, op. cit., hal. 103.

${ }^{26}$ Yaitu fatwa tentang Bayi Tabung dan Pencangkokan dalam Sorotan Hukum Islam, lihat PP. Muhammadiyah Majlis Tarjih, Bayi Tabung dan Pencangkokan dalam Sorotan Hukum Islam, Keputusan Muktamar Tarjih Muhammadiyah ke-21 di Klaten Tahun 1980, (Yogyakarta: Penerbit Persatuan, 1980).

${ }^{27}$ Himpunan fatwa tersebut telah dihimpun dalam buku Tanya Jawab Agama 1, 2. 3, dan 4. diterbitkan oleh Yayasan Penerbit Pers "Suara Muhammadiyah".
} 
pembentukan forum ini merupakan realisasi dari usulan dalam Muktamar Muhammadiyah di Sala, tahun $1985 .^{28}$

Selain melalui dua produk di atas, juga memiliki sejenis wacana yang berupa tulisan ilmiah yang diterbitkan melalui jurnal Tarjih. Dilihat dari segi daya mengikatnya atas warga Muhammadiyah, Muhammad Azhar mengibaratkan, yang pertama sangat mengikat, hukumnya 'wajib mughallazhah', kedua, tidak terlalu mengikat, hukumnya 'Sunnah muakkadah', dan ketiga sifatnya mubah. ${ }^{29}$

Keputusan hukum Majlis Tarjih dilakukan dengan cara musyawarah, melalui ijtihād jamā'i. Dasar utama dalam ber-istidlāl adalah Alquran, as-Sunnat

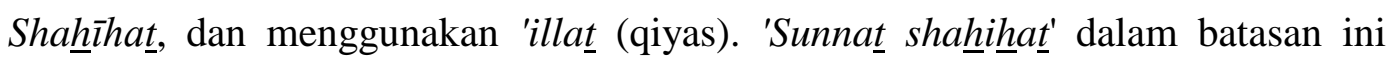
menurut interpretasi Asymuni Abdurrahman, tokoh Majlis Tarjih, adalah Sunnat Maqbūlat, yaitu Sunnah yang diterima sebagai dalil hukum, meski sejak dari awal belum secara konsisten dilaksanakan, sebagaimana terdapat dalam buku Himpunan Putusan Tarjih (HPT) telah menetapkan hukum berdasarkan pada Hadis dla' $^{\prime} f^{30}{ }^{30}$

Dasar mutlak berhukum Majlis Tarjih adalah Al Quran dan Hadis. Hal-hal yang menyangkut bidang di luar ibadah ma $\underline{h} d l a \underline{t}$ untuk argumen yang tidak terdapat dalam dua sumber tersebut dipergunakan ijtihad dan istinbāth (formulasi) dari nash melalui persamaan 'illat sebagaimana telah dilakukan oleh ulama salaf dan khalaf. ${ }^{31}$ Metode ini dikenal dengan qiyas.

Dalam hal kembali kepada Al - Quran, yang dimaksud oleh Majlis Tarjih adalah kembali kepada ayat-ayat dalam Al - Quran, bukan pada kitab-kitab tafsir yang memuat tafsiran ayat-ayat. Hal ini dibuktikan dalam Himpunan Putusan Majlis Tarjih yang tidak ditemukan rujukan kitab tafsir. Prinsip kembali kepada Hadis, mereka tidak merujuk pada komentator hadis. ${ }^{32}$ Namun dalam aplikasinya, Majlis Tarjih tidak cukup konsisten, seperti dapat dilihat dalam pengutipan Hadis, hanya merujuk pada sejumlah sumber kedua, buku komentator atau kompilasi

\footnotetext{
${ }^{28}$ Lihat PP. Muhammadiyah Majlis Tarjih, Tanya Jawab Agama 2, (Yogyakarta: Suara Muhammadiyah, 2003), hal. 214-215.

${ }^{29}$ Lihat Muhammad Azhar, Posmodernisme Muhammadiyah, (Yogyakarta: Suara Muhammadiyah, 2005), hal. 149-150.

${ }^{30}$ Asymuni Abdurrahman, Manhaj Tarjih Muhammadiyah, (Yogyakarta: Pustaka Pelajar, 2002). hal. 9.

${ }^{31}$ Lihat PP. Muhammadiyah Majlis Tarjih, Himpunan Putusan Tarjih, hal. 278.

${ }^{32}$ Rifyal Ka'bah, op. cit., hal. 298.
} 
Hadis, seperti al-Fath al-Bāri, Nail al-Authār, Subul al-Salām, Riyādl al-Shālih̄īn, dan lain-lain, sedikit sekali diduga merujuk pada kitab induk hadis, misalnya diriwayatkan oleh al-Bukhāri dalam shahīh $\underline{h}$-nya, Muslim dalam shahㅡhㅡ-nya, dan lainnya. $^{33}$

Sikap dan pendirian Majlis Tarjih tidak mengikatkan diri terhadap pendapat para imam mazhab tertentu, tetapi langsung kepada sumber yang digunakan para imam mazhab, Al - Quran dan Hadis, menurut mereka adalah sejalan dengan pesan para imam mazhab itu sendiri. ${ }^{34}$ Secara manhāji, Majlis Tarjih juga mengikuti metode yang dilakukan oleh para ulama Salaf maupun Khalaf, seperti

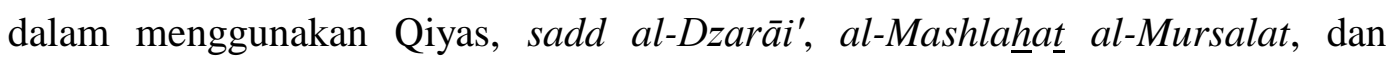
lainnya yang merupakan aspirasi ulama terdahulu dari berbagai mazhab, tetapi dalam keputusan Majlis Tarjih dipandang sebagai pendapat sendiri. ${ }^{35}$ Demikian juga dalam kutipan tafsir, dapat dipastikan menggunakan pendapat mufassir tertentu, dan dalam bidang hadis juga menggunakan pendapat komentator hadis tertentu, tetapi pendapat-pendapat tersebut dipandang sebagai pendapat sendiri, seperti tampak dalam hampir seluruh keputusannya tidak ditemukan mengutip pendapat orang lain. ${ }^{36}$ Meskipun tidak mengikatkan diri dan mengikuti pendapat tertentu, model atau metode ijtihad yang dipergunakan tidak keluar dari metode yang biasanya digunakan oleh ulama masa lalu, meliputi Ijtihād Bayāni, Ijtihād Qiyāsi, dan ijtihād Istishlāhi. ${ }^{37}$

Penjelasan dari tiga jenis metode ijtihad tersebut adalah sebagai berikut:

1. Ijtihād bayāni adalah menjelaskan hukum yang kasusnya telah terdapat dalam nash Al - Quran dan Hadis.

2. Ijtihād qiyāsi adalah menyelesaikan kasus baru, dengan cara menganalogikannya dengan kasus yang hukumnya telah diatur dalam Al Quran dan Hadis.

\footnotetext{
${ }^{33}$ Misalnya, lihat PP. Muhammadiyah Majlis Tarjih, Himpunan Putusan Majlis Tarjih Muhammadiyah, op. cit., hal. 90, 91 .

${ }^{34}$ Lihat Asymuni Abdurrahman, op. cit., hal. 14-16.

${ }^{35}$ Lihat PP. Muhammadiyah Majlis Tarjih, Himpunan Putusan Majlis Tarjih Muhammadiyah, hal. 278.

${ }^{36}$ Rifyal Ka'bah, op. cit., hal. 112.

${ }^{37}$ Lihat H. Asjmuni Abdurrahman, op. cit., hal. 113.
} 
3. Ijtihād ishtishlāh $\underline{i}$ adalah menyelesaikan beberapa kasus baru yang tidak terdapat dalam kedua sumber di atas, dengan cara menggunakan penalaran yang didasar-kan atas kemaslahatan. ${ }^{38}$

Dilihat dari kelaziman ilmiah akademis, mengkritisi isi Himpunan Keputusan Majlis Tarjih dalam ber-istinbāth langsung dari Al - Quran dan Hadis, dalam sistem pengutipan rujukan terdapat kelemahan, misalnya tidak menyebutkan dasar / dalil yang menjadi rujukan, kutipan ayat Al - Quran disebutkan nama surat dan nomer ayat, Rāwi/Mukharrij Hadis disebutkan tetapi buku induk Hadis asal pengambilan tidak disebutkan dan tidak disertai catatan kaki. Juga, tidak ditemukan adanya pendapat mufassir dalam menafsirkan ayat yang dijadikan rujukan. ${ }^{39}$ Banyak keputusan yang tidak menyebutkan jalan istidlāl dan istinbāth-nya, kecuali yang dikeluarkan sesudah Muktamar Muhammadiyah ke-21 di Klaten, tahun 1980.

Majlis Tarjih juga berpendirian tidak mengikatkan diri kepada suatu mazhab, tetapi pendapat imam-imam mazhab dapat menjadi pertimbangan dalam menentukan hukum. ${ }^{40}$ Dalam hal 'mempertimbangkan' di sini, Majlis Tarjih masih mempersyaratkan jika sesuai dengan jiwa Alquran dan Sunnah atau dasar lain yang dipandang kuat. Ijmak shahabat dapat diterima sebagai dasar suatu keputusan. Untuk menghindari akan terjadi fitnah dan mafsadat, asas sadd alDzarīat dapat digunakan. Dalam bidang yang termasuk masalah duniawi, penggunaan akal sangat diperlukan demi kemaslahatan umat. Dalam memahami nash yang terkait dengan masalah akidah, lebih mengedepankan makna zhāhir daripada $t a ' w \bar{l} l^{41}$

Meski tidak 'mengikatkan diri dengan pendapat tertentu', dalam memahami dalil-dalil dari nash pasti menggunakan metode tertentu melalui ilmu Ushul Fiqh. Ini juga dapat disimpulkan dari pernyataan dalam poin 10 HPT yang menyatakan

\footnotetext{
${ }^{38}$ Lihat Fathurrahman Djamil, Metode Ijtihad Majlis Tarjih Muhammadiyah, (Jakarta: Logos, 1995), hal. 78. Lihat juga H. Asjmuni Abdurrahman, Ibid., hal.113.

${ }^{39}$ Kepastian merujuk pendapat mufassir tertentu tidak dapat dipungkiri, berdasarkan realitas jika mengkritisi keputusan Majlis Tarjih, pendapat dan pendiriannya tidak ada yang sama sekali baru, artinya, tidak ada keputusan atau pendapatnya itu belum pernah disampaikan oleh ulama terdahulu. Lihat Rifyal Ka'bah, op. cit., hal. 298.

${ }^{40}$ Lihat Asymuni Abdurrahman, op. cit., hal. 12. Lihat juga Lampiran I, 'Pokok-pokok Manhaj Majlis Tarjih yang telah dilakukan dalam menetapkan keputusan' dalam Fathurrahman Djamil, op. cit., hal. 161.

${ }^{41}$ Lihat Asymuni Abdurrahman, Ibid., hal. 12-13.
} 
bahwa 'penggunaan dalil-dalil untuk menetapkan sesuatu hukum dilakukan dengan komprehensif, utuh, bulat, dan tidak terpisah-pisah'. ${ }^{42}$ Metode penetapan hukum yang ikut menjadi pertimbangan dalam menentukan suatu ketentuan, seperti menggunakan sadd al-Dzari'at, Mashlahat, dan kaidah hukum Islam (qawāid Fiqhiyyat $).{ }^{43}$ Segi ini juga nampak dalam dokumen putusan Majlis Tarjih yang secara khusus ada tinjauan atau berdasarkan Ushul Fiqh. ${ }^{44}$

Pendirian Majlis Tarjih terhadap masalah yang sudah diijtihadkan oleh para ulama masa lalu, dilakukan tarjih, ditetapkan melalui pertimbangan pendapat para ulama yang dinilai paling kuat menurut mereka, dengan penilaian pendapat yang paling dekat dengan Al - Quran dan Hadis. Dilihat dari hasil tarjih yang dilakukan, ternyata tidak terdapat pendapat baru, di luar dari pendapat yang ada. ${ }^{45}$

Sekurangnya ada dua penilaian berbeda terhadap corak ijtihad Majlis Tarjih, Arbiyah Lubis menilai lebih tepat dimasukkan dalam kategori al-Mujtahid fi alMadzhab atau al-Mujtahid al-Muqayyad. ${ }^{46}$ Menurut Fathurrahman Djamil, bahwa Muhammadiyah telah melakukan ijtihad jamā'i, maka dapat dikatakan sebagai mujtahid, namun tidak dapat disebut sebagai mujtahid muthlaq atau mujtahid mustaqil, tidak pula mujtahid fi al-Madzhab, ia lebih mirip dengan mujtahid murajjih atau ahl al-Tarjīh sebagaimana dikenal dalam peringkat mujtahid dalam ilmu Uhul Fiqh. ${ }^{47}$

Dalam menetapkan hukum dan merespon isu kontemporer, menurut Fathurrahman Djamil, berbagai aplikasi metode ijtihad sebagaimana dirumuskan dalam ilmu Ushul Fiqh digunakan oleh Majlis Tarjih. Metode Istihssān, misalnya digunakan dalam menentukan hukum KB, strerilisasi, dan aborsi. ${ }^{48}$ Hukum bayi tabung, transplantasi jaringan atau organ tubuh manusia digunakan metode alMashlahat al-Mursalat. ${ }^{49}$ Meski demikian dalam penerapan metode, kelihatan bahwa Majlis Tarjih tidak konsisten dalam penggunaan metode atau penerapan

\footnotetext{
${ }^{42}$ Ibid., hal. 99.

${ }^{43}$ PP. Muhammadiyah Majlis Tarjih, Himpunan, op. cit., hal. 273-274.

${ }^{44}$ Ibid., hal. 300-301

${ }^{45}$ Arbiyah Lubis, Pemikiran Muhammadiyyah dan Muhammad Abduh, Suatu Studi Perbandingan, (Jakarta: Bulan Bintang, 1993), hal. 174-175. Lihat juga Rifyal Ka'bah, op. cit., hal. 298.

${ }^{46}$ Arbiyah Lubis, Ibid., hal. 183-184.

${ }^{47}$ Fathurrahman Djamil, op cit., hal. 59.

${ }^{48}$ Ibid., hal. 152-153.

${ }^{49}$ Ibid., hal. 153-154,
} 
ijtihadnya, atau karena terlalu banyak metode yang dipakai dalam menyelesaikan kasus tertentu. ${ }^{50}$ Namun demikian jika diukur dari kerangka teori Ushul Fikih, terdapat sejumlah kelemahan, seperti dalam kasus pembolehan $\mathrm{KB}$ atas dasar maslahat harusnya bersifat umum, Majlis Tarjih hanya melihatnya dari segi kepentingan individual. Dalam penentuan adanya kemaslahatan, seharusnya atas dasar yang meyakinkan, bukan hipotesis, seperti ketika menentukan hukum asuransi jiwa dengan tidak menyertakan keterangan yang meyakinkan. Kadangkadang Majlis Tarjih tidak menentukan hukum sesuatu secara jelas, seperti terhadap hukum bayi tabung, asuransi jiwa yang dikelola oleh swasta, haram atau mubah. $^{51}$

Dari segi format keputusan, Majlis Tarjih menyusunnya dalam bentuk argumentatif, mengikuti format modern, digunakan istilah menimbang, mengingat, memperhatikan, memutuskan dan istilah-istilah lainnya yang sejenis itu, merujuk pada sumber-sumber Islam, juga sering merujuk pada perundangundangan yang berlaku di Indonesia.

\section{MUI (Majlis Ulama Indonesia)}

Kiprah Komisi Fatwa MUI, sejak dibentuk pada 26 Juli 1975 sudah banyak mengeluarkan fatwa hukum Islam. Sebagaimana lembaga-lembaga fatwa yang lain, fatwa MUI dikeluarkan untuk merespon persoalan yang muncul di masyarakat.

Secara metodologis, dalam menetapkan hukum, menggunakan dasar sebagaimana dirumuskan secara akademis dalam ilmu-ilmu syariah, dengan urutan Al - Quran, Sunnah, Ijmak, dan Qiyas. Juga memperhatikan pendapat imam - imam mazhab dan fuqaha dengan mengadakan penelitian terhadap dalil dalil dan wajah istidlāl-nya guna mendapatkan dalil yang terkuat dan lebih bermaslahah bagi umat, jika tidak ditemukan maka dilakukan ijtihād Jamā' $i{ }^{52}$

\footnotetext{
${ }^{50}$ Ibid, hal. 157.

${ }^{51}$ Ibid., hal. 156-157.

${ }^{52}$ Sesuai dengan pasal 1 Keputusan Dewan Pimpinan Majlis Ulama Indonesia, no. Kep.069/MUI/1986 tentang Pedoman dan Tata Cara Penetapan Fatwa Majlis Ulama Indonesia. Lihat Sekretariat MUI, Muqaddimah Pedoman Dasar Pedoman Rumah Tangga Pedoman Pentapan Fatwa, (Jakarta: MUI, 1986), hal. 26. Juga, Sekretariat MUI, Himpunan Keputusan dan Fatwa Majlis Ulama Indonesia, hal. 15.
} 
Dalam ungkapan yang sedikit berbeda dinyatakan 'Jika tidak terdapat dalam kitābullāh dan Sunnah Rasul, keputusan fatwa hendaklah tidak bertentangan dengan ijmak, qiyas, dan dalil-dalil hukum yang lain, seperti Istih̆sān, Masālih Mursalaț, dan Sadd adz-Dzarī'at. ${ }^{.53}$

Dilihat dari konsistensi atas komitmennya menetapkan hukum berdasarkan urutan dalil yang digunakannya, sebagaimana terdapat dalam Himpunan Keputusan dan Fatwa MUI, sebagian tergambar secara sistematis, namun tidak sedikit sama sekali tidak menyertakan dalil / nash yang dijadikan dasar. Penyusunan dalil tidak mutlak berurutan sebagaimana tertib urutan di atas. Kutipan nash Al - Quran secara konsisten dituliskan nama surat dan nomer ayat. Kutipan Hadis tidak selalu disertakan rāwi-nya, status kualitas Hadis hanya sebagian disebutkan, demikian juga sanad Hadisnya, sumber buku Hadis hanya sedikit sekali dicantumkan. Kutipan dari kitab fikih dicantumkan judul buku, jilid, halaman, dan hanya sedikit nama penyusunnya dicantumkan,

Dari segi metodologi istinbāth (formulasi) hukum, MUI tidak mengikuti satu pola tertentu, terlihat adanya beberapa fatwa berawal dengan dalil - dalil dari Al - Quran sebelum melacak Hadis atau naskah-naskah fiqh. Beberapa fatwa langsung meneliti naskah-naskah fiqih dan langsung menganalogikan masalah yang dibahas tanpa merujuk pada ayat Al - Quran atau Hadis. Bahkan, ada beberapa fatwa tidak menyertakan dalil sama sekali, langsung menyatakan isi fatwanya. $^{54}$

Dilihat dari format penyusunan keputusan, fatwa - fatwa sebelum tahun 2000 terlihat tidak ada format khusus yang baku, kadang-kadang disampaikan mengikuti format modern seperti menimbang, mengingat, mendengar, memperhatikan, memutuskan, atau memutuskan, menetapkan. Sejumlah fatwa langsung disampaikan isi fatwa terkait tanpa didahului dengan sistematika di atas. Fatwa - fatwa yang dikeluarkan setelah tahun 2000, secara konsisten disusun

\footnotetext{
${ }^{53}$ Lihat poin 2 pasal 2 Pedoman Penetapan Fatwa Majlis Ulama Indonesia, nomer U-96/MUI/X/1997.

${ }^{54}$ Lihat Muhammad Atho Mudzhar, Fatwa-fatwa Majlis Ulama Indonesia: Sebuah Studi tentang Pemikiran Hukum Islam di Indonesia, 1975-1988 (Edisi Dwibahasa), (Jakarta dan Leiden: INIS., 1993), hal. 129.
} 
mengikuti format modern, dasar dan dalil yang dijadikan sebagai alasan, waktu ditetapkannya, dan ditandatangani oleh pimpinan, ketua dan sekretaris.

\section{Dewan Hisbah PERSIS}

Dewan Hisbah merupakan salah satu dewan yang dibentuk dalam PERSIS (Persatuan Islam), merupakan dewan pertimbangan dan pengkajian syarak dalam jam'iyyah, berkewajiban meneliti hukum-hukum Islam, membuat petunjuk pelaksanaan, serta mengawasi pelaksanaannya. ${ }^{55}$ Sebelum bernama Dewan Hisbah, lembaga ini bernama Majlis Ulama. Peran dan fungsinya dituangkan dalam Bab V fasal I dan 2 Qanun Asasi Persatuan tahun 1957. Pada pasal I ayat 1 dinyatakan bahwa 'Persatuan Islam mempunyai Majlis Ulama yang bertugas menyelidiki dan menetapkan hukum-hukum Islam berdasar Al - Quran dan Sunnah, dan pusat pimpinan menyiarkannya. ${ }^{56}$ Aktivitasnya telah dimulai bersamaan dengan berdirinya PERSIS pada tahun 1923-an. ${ }^{57}$

Awal sejarah terbentuknya Dewan Hisbah dimulai pada Muktamar ke-6 (Bandung, 15-18 Desember 1956) secara resmi membentuk Majlis Ulama PERSIS. Sebelum terbentuk Dewan Hisbah atau Majlis Ulama, kebiasaan merespon dan mendiskusikan isu yang berkembang telah sejak lama dilakukan oleh tokoh pendiri PERSIS melalui diskusi keagamaan di Gang Pakgade yang diikuti oleh para pedagang yang disebut "Urang Pasar". ${ }^{58}$ Dari sinilah deklarasi lahirnya organisasi yang melekatkan dirinya dengan semangat pembaharuan Islam (gerakan Tajdid), bersemboyan 'Kembali kepada Al - Quran dan Sunnah serta membersihkan Islam dari khurafat dan bid'ah yang mengotorinya.' Dalam perkembangan selanjutnya, mereka membentuk PERSIS. ${ }^{59}$

\footnotetext{
${ }^{55}$ Pasal 13, 14, dan 15 Qanun Asasi Qanun Dakhili I. Lihat PP. PERSIS 'Sejarah PERSIS' di http://www.PERSIS.or.id/site/modules.php?name=Content\&pa=showpage \& pid=5. Diakses pada 2 Januari 2007

${ }^{56}$ Dadan Wildan, Sejarah Perjuangan PERSIS 1923-1963, (Bandung: Gema Syahida, 1995), hal. 141.

${ }^{57}$ Badri Khaeruman, Pandangan Keagamaan Persatuan Islam, Sejarah, Pemikiran, dan Fatwa Ulamanya, (Bandung: Granada, 2005), hal. 41.

${ }^{58}$ Sebutan bagi sekelompok masyarakat yang memiliki lebih banyak kebebasan terhadap adat istiadat, lebih bebas dibandingkan dengan para pegawai atau petinggi/ bangsawan Sunda. Risalah No. 3 Th XXVIII, Mei, 1990, hal. 12, dikutip oleh Dadan Wildan, op. cit., hal. 37.

${ }^{59}$ Dadan Wildan, Ibid., hal. 27.
} 
Ketika masih bernama Majlis Ulama, di bawah kepemimpinan A. Hassan, sering diutus untuk mengikuti sidang Majlis Tarjih Muhammadiyahal. ${ }^{60}$ Pada Muktamar PERSIS VIII tahun 1967, di bawah kepemimpinan K.H.E Abdurrahman, Majlis Ulama berganti nama menjadi Dewan Hisbah, hal ini tertuang dalam Qanun Asasi (Anggaran Dasar) PERSIS hasil Muktamar ke-8 pada bab II pasal II. Disebutkan, bahwa tugas dan kewajiban Dewan Hisbah adalah membantu Pimpinan Pusat dalam meneliti hukum-hukum Islam dan mengawasi pelaksanaannya serta memberikan teguran atas pelanggaran-pelanggaran hukum Islam yang dilakukan oleh para pemimpin dan anggota jam'iyyah dengan cara yang khusus. ${ }^{61}$ Tugas intinya adalah menyelidiki dan menetapkan hukum-hukum Islam berdasar pada Al - Quran dan Sunnah. ${ }^{62}$ Peran dan tugas ini dalam perkembangan selanjutnya cukup besar dan berpengaruh dalam PERSIS, terutama dalam masalah pengambilan keputusan (istinbāth) hukum Islam.

Di bawah kepemimpinan K.H.E. Abdurrahman (1962-1983), Dewan Hisbah dipimpin seorang diri, segala permasalahan dijawab seorang diri. Dengan demikian, secara organisatoris Dewan Hisbah mengalami kevakuman. Jawabanjawaban atas berbagai isu dan pertanyaan disampaikan melalui mimbar-mimbar dan majalah 'Risalah' yang dipimpinnya sendiri. ${ }^{63}$

Sepeninggal K.H.E. Abdurrahman (12 April 1983), kepemimpinan PERSIS diserahkan kepada K.H.A Latief Muchtar, Dewan Hisbah diaktifkan kembali. Sejak saat itu sejumlah respon terhadap isu yang berkembang di masyarakat mulai mendapat perhatian, banyak keputusan hukum dilahirkan dan sering mengadakan rapat, dokumentasi keputusannya dapat dijumpai. Berbeda dengan sebelum tahun 1983, dokumen keputusan-keputusannya tidak terlacak lagi, meski diakui banyak masalah telah diputuskan. ${ }^{64}$ Sejak tahun 1990, Dewan Hisbah PERSIS telah berijtihad kolektif, secara intensif menghasilkan fatwa-fatwa kategori muamalah, tercatat setiap tahun mengadakan sidang. Hampir seluruh isu yang berkembang di

\footnotetext{
${ }^{60}$ Ibid., hal. 142.

${ }^{61}$ Sekretariat PERSIS, Qanun Asasi Persatuan Islam, (Bandung: PERSIS, 1968).

${ }^{62}$ Lihat Dadan Wildan, op. cit., hal. 141.

${ }^{63}$ Lihat Shiddiq Amien (Ed.), Kumpulan Keputusan Dewan Hisbah Persatuan Islam, (Bandung: PERSIS, 2002), hal. 7-8.

${ }^{64}$ Ibid., hal. 17.
} 
masyarakat telah difatwakan. Meski masih dalam jumlah terbatas, sebagian keputusan Dewan Hisbah sejak diaktifkan kembali tahun 1983 telah dibukukan oleh Dewan Hisbah pada tahun 2001, namun, sebagian keputusan masih merupakan arsip - arsip jam'iyyah.

Karakteristik penetapan hukum yang dilakukan oleh PERSIS bersifat literalisme murni, terikat dengan khazanah intelektual klasik maupun modern, tetap menggunakan sumber dasar, Al - Quran dan Hadis juga mencakup ilmu-ilmu yang terkait, dan mengikuti metode sebagaimana dijabarkan dalam Ilmu Ushul Fikih serta Qawāid Fiqhiyyah. Namun dalam aplikasinya sering berseberangan dengan pemahaman yang sebelumnya dianggap baku. ${ }^{65}$

Secara umum topik - topik yang difatwakan Dewan Hisbah tuntas dalam satu sidang muktamar, namun kadang-kadang meski topik masih terkait, fatwa belum tuntas di-instinbath-kan dalam satu sidang, masih menyisakan persoalan sehingga perlu disusul dengan fatwa lanjutan dalam sidang berikutnya, seperti fatwa tentang transplantasi, pada sidang Dewan Hisbah ke-6 (15 April 1990) telah menetapkan hukum tentang transplantasi, 5 tahun kemudian pada sidangnya ke-12 (25 Juni 1995) menetapkan hukum serupa tentang transplantasi dengan organ binatang haram. Setelah itu, 5 tahun kemudian (15 April 2000) menetapkan hukum transplantasi dengan tubuh non-muslim. ${ }^{66}$

Sebelum Muktamar tahun 1983, fatwa putusan hukum PERSIS yang terdengar hanya merupakan keputusan individual, temanya lebih banyak menyangkut ibadah mahdlat , bersifat reaktif sesuai dengan judulnya 'Soal Jawab' karya individual dari seorang tokoh, Ahmad Hassan (1887-1958) dkk. ${ }^{67}$ Isi buku tersebut diasumsikan sebagai pendapat PERSIS. Dalam buku tersebut secara tidak

\footnotetext{
${ }^{65}$ Misalnya, dalam memberlakukan ijmak hanya mengikuti dan mengakui ijmak Shahabat. Terhadap ijmak ulama, akan diikuti jika benar-benar bersandar pada Alquran dan Hadis maka wajib menerimanya, jika hanya berdasarkan pada pendapat maka tidak wajib menerimanya. Lihat tulisan Abdul Qadir Hassan dalam A. Hassan, Soal Jawab Masalah Agama 1-2, (Bangil: CV. Pustaka Tamaam, 1985), hal. 9-32. Hooker, op. cit., hal. 83.

${ }^{66}$ Ibid., hal. 68-69, 85-86, 91-92.

${ }^{67}$ Dihimpun dalam buku Soal - jawab Masalah Agama, disusun oleh 3 orang: A. Hassan (A.H), Moh. Ma'sum (Md. Mm.), dan H. Mahmud Aziz (H.M.A). Buku ini dibagi dalam 4 jilid, terbitan I dilakukan oleh PERSIS Bandung dan Bangil, kemudian c.v. Diponegoro dan Penerbit PERSIS Bangil serta CV. Pustaka Tamaam Bangil (1985). Dalam buku tersebut selalu dicantumkan nama penjawab dengan inisial, ini menunjukkan bahwa jawaban tersebut adalah pendapat individual. Sangat jelas, penjawabnya tidak hanya tiga orang, tetapi lebih, terbukti ada beberapa inisial tercantum dalam lembar jawab yang tidak disebutkan nama terangnya, misalnya AQ (barangkali maksudnya adalah Abdul Qadir), dan AK.
} 
konsisten mencantumkan kapan soal jawab itu berlangsung, sangat sedikit mencantumkannya, seperti pertanyaan tentang membaca al-Fätihat di belakang imam oleh seorang penanya berinisial H dari Batavia C, 29 Juni 1938, dijawab oleh Alimin dari atau di Payakumbuh 16 Januari $1941 .^{68}$ Tema-tema muamalah kontemporer, mulai dibahas sejak Muktamar Dewan Hisbah tahun 1983. Fatwa fatwa tersebut lebih bersikap reaktif terhadap persoalan, juga bersifat proaktif terhadap persoalan yang sedang terjadi atau diprediksikan akan kehadirannya.

Guna lebih mengarahkan kinerja Dewan Hisbah, pada tahun 1994 dibentuk tiga komisi, yaitu komisi ibadah mahdlah, komisi muamalah, dan komisi aliran sesat. ${ }^{69}$ Manhāj yang digunakan dalam istinbāth hukum dengan tegas dinyatakan tidak mengikatkan diri dengan satu mazhab, tetapi pendapat mazhab menjadi pertimbangan. Metode resmi yang dipergunakan untuk memutuskan hukum, dengan dasar utama adalah Al - Quran dan Hadis yang shahih. ${ }^{70}$ Namun, dalam praktiknya dalam ber-istidlāl tidak berbeda dengan yang telah dirumuskan dalam Ilmu Ushul Fiqh, menggunakan dasar Al - Quran, Hadis, dan ijtihad, tetapi secara teknis ada kecenderungan tersendiri, misalnya dalam ber-istidlāl dengan Al Quran mengambil sikap memilih cara khusus, seperti lebih mendahulukan makna zhāhir dan hakiki daripada $t a^{\prime} w \bar{l} l$ dan majāzi. Dalam bidang akidah dipilih cara tafwìdl. Menerima isi Al - Quran meski nampaknya bertentangan dengan akal. Menerima nāsikh menolak mansūkh Al - Quran, menerima tafsir Shahabat, dan mengutamakan tafsir bi al-Ma'tsūr. Dalam ber-istidlāl terhadap Hadis, hanya menggunakan Hadis Shahㅡh atau hasan, dengan mempertimbangkan sejumlah batasan dalam menerima dan menolak suatu Hadis. Terhadap masalah yang tidak ditemukan nashnya dalam Al- Quran dan Hadis, dilakukan ijtihad jamā'i dengan batasan tertentu. $^{71}$

Pada saat yang lalu, dalam menginventarisasi keputusan yang di-istinbāthkan, tidak mencantumkan teks dalil yang mendasarinya. Kelaziman yang

\footnotetext{
${ }^{68}$ A. Hassan, op. cit., hal. 1401-1405

${ }^{69}$ Shiddiq Amien, op. cit., hal. 15-16.

${ }^{70}$ Lihat Keputusan sidang Dewan Hisbah ke-3 dan ke-4 tentang Metodologi Pengambilan Keputusan Hukum Islam, dikeluarkan oleh PP. Persatuan Islam, Bandung pada 13 Shafar $1412 \mathrm{H}$.

${ }^{71}$ Batasan lengkap dan detail menyangkut hal ini, lihat Ibid., hal. 35-40. Lihat pula Badri Khaeruman, op. cit., hal. 62-63. Lihat pula di PP. Persatuan Islam, "Metodologi dalam Menetapkan Hukum Islam" di http://www.persatuanislam.or.id/home.php?t=non berita\&arsip=fatwa. Diakses 18 Mei 2012.
} 
dilakukan, merujuk pada makalah ilmiah yang temanya terkait dengan masalah yang akan dibahas hukumnya dalam sidang, disusun oleh seorang ulama dari kalangan intern yang dinilai menguasai bidang terkait. Untuk bidang di luar kompetensi ulama, kadang mengundang pakar dari kalangan terkait untuk menjelaskan topik terkait. Setelah disajikan makalah, dilanjutkan dengan diskusi oleh seluruh anggota Dewan Hisbah.

Dalam menetapkan hukum isu-isu aktual, yang tidak dinyatakan secara eksplisit dalam nash, ditempuh dengan prosedur qiyas atau istihlsān. Jika masalahnya tidak terjangkau oleh nash, maka dikaji dengan kaidah-kaidah alMashlahat al-Mursalat dan al-Dzarī'at, juga menggunakan metode analisis hukum melalui kaidah-kaidah fiqh. ${ }^{72}$

Dalam sistem penyusunan penukilan dalil tidak mutlak berurutan sebagaimana tertib urutan di atas. Kutipan nash Al - Quran dituliskan nama surat dan nomer ayat. Kutipan Hadis tidak selalu disertakan rāwi/mukharrij-nya, status kualitas Hadis hanya sebagian disebutkan, demikian juga sanad Hadis, sumber buku Hadis hanya sedikit sekali dicantumkan, kutipan dari kitab fikih dicantumkan judul buku, jilid, dan halaman, sedangkan nama penyusun sebagian besar tidak dicantumkan. Bahkan, di antara fatwa Dewan Hisbah tidak menyertakan dalil sama sekali, langsung menyatakan isi fatwanya. Dilihat dari segi penyusunan format keputusannya, istinbāth Dewan Hisbah disusun dalam bentuk argumentatif, mengikuti format modern, juga menggunakan istilah menimbang, mengingat, dan istilah-istilah lainnya yang sejenis itu, merujuk pada sumber-sumber hukum Islam. Teks dalil-dalil yang dijadikan sebagai pendukung tidak disertakan dalam keputusan. Dalam 'Kumpulan Keputusan Dewan Hisbah Persatuan Islam' berbagai dalil dan argumen yang dikutip adalah bahan atau makalah individual yang disampaikan oleh orang dalam Dewan Hisbah tentang tema yang akan ditetapkan fatwanya, biasanya telah dipresentasikan di hadapan anggota sidang sebelum dikeluarkannya fatwa. Namun format penyusunan fatwa yang dlakukan akhir-akhir ini, digunakan kelaziman sistematika keputusan, mencantumkan judul fatwa, tanggal ditetapkan dan tempat serta waktu sidang

\footnotetext{
${ }^{72}$ Dede Rosyada, Metode Kajian Hukum Dewas Hisbah Persis, (Jakarta: Logos, 1999)., hal. 189.
} 
diselenggarakan, menggunakan kata mengingat, memperhatikan dan seterusnya, dalil-dalil yang mendasarinya, baik dari Alquran lengkap nama surat dan ayat maupun hadis lengkap dengan sanad dan rawinya, kaidah fiqhiyyah, dan ditandatangani oleh ketua dan sekretaris. ${ }^{73}$

\section{Perbandingan Metodologi Penetapan Hukum Lembaga-lembaga Fatwa di Indonesia}

Dari jabaran di atas terlihat bahwa dari segi metode penetapan hukum Islam dan sistematika penyusunan surat keputusan, serta forum / sidang penetapan fatwa, masing-masing lembaga mempunyai tipe tersendiri, di antaranya ada yang sama. Bahtsul Masail mempunyai kekhususan tersendiri, dari sisi metode penetapan hukum, sistem penyusunan fatwa, serta keterikatannya dengan mazhab sangat terlihat kuat. Secara umum Majlis Tarjih ada kesamaan dengan Dewan Hisbah dari sisi metode penetapan hukum, sistem penyusunan fatwa, serta ketidakterikatannya dengan mazhab tertentu. Juga dalam semboyan kembali kepada Al - Quran dan Hadis, serta penggunaan metode penetapan hukum yang tidak dinyatakan secara jelas dalam fatwanya. Secara umum MUI bersifat fleksibel dalam menggunakan metode penetapan hukum serta tidak menetapkan mazhab tertentu sebagai acuan. ${ }^{74}$ Untuk lebih memperjelas, dapat dilihat pada tabel berikut:

\begin{tabular}{|c|c|c|c|c|c|}
\hline No & $\begin{array}{c}\text { NAMA } \\
\text { LEMBAGA } \\
\text { FATWA }\end{array}$ & $\begin{array}{c}\text { METODE } \\
\text { PENETAPAN } \\
\text { HUKUM }\end{array}$ & $\begin{array}{c}\text { SISTEMATIKA } \\
\text { PENYUSUNAN } \\
\text { KEPUTUSAN }\end{array}$ & $\begin{array}{c}\text { FORUM/SIDANG } \\
\text { PENETAPAN } \\
\text { HUKUM }\end{array}$ & $\begin{array}{c}\text { KETERIKATAN } \\
\text { DENGAN MAZHAB } \\
\text { TERTENTU }\end{array}$ \\
\hline 1 & $\begin{array}{l}\text { Bahtsul Masail } \\
\text { NU }\end{array}$ & $\begin{array}{l}\text { - } \text { Merujuk ibarat } \\
\text { kitab } \\
\text { - } \text { taqrīr jamā'i } \\
\text { - Ilhaq } \\
\text { - Manhaji }\end{array}$ & Tanya-jawab & $\begin{array}{l}\text { - Muktamar, } \\
\text { - Munas, } \\
\text { - Konbes PB } \\
\text { Syuriah NU }\end{array}$ & $\begin{array}{l}\text { Mengikatkan diri pada } \\
\text { Mazhab Ahlussunah } \\
\text { wal Jamaah }\end{array}$ \\
\hline 2 & $\begin{array}{l}\text { Majlis Tarjih } \\
\text { Muhammadiyah }\end{array}$ & $\begin{array}{l}\text { - } \quad \text { Ijtihād bayāni } \\
\text { - } \quad \text { Ijtihad qiyasi }\end{array}$ & $\begin{array}{l}\text { Sistem surat } \\
\text { keputusan modern }\end{array}$ & Muktamar Khususi & $\begin{array}{l}\text { Tidak mengikatkan } \\
\text { diri pada mazhab }\end{array}$ \\
\hline
\end{tabular}

\footnotetext{
${ }^{73}$ Seperti terlihat dalam fatwa Dewan Hisbah Persis yang dikeluarkan pada 18-19 Februari 2012 tentang hukum Donor Darah, Pemanfaatan sel Punca, dan Hukum Bank ASI oleh PP Persis, di http://www.persatuanislam.or.id/home.php?t=non berita\&arsip=fatwa. Diakses 18 Mei 2012.

${ }^{74}$ Lihat Zuhroni, Respon Ulama Indonesia terhadap Isu-isu Kedokteran dan Kesehatan Modern, (Jakarta: Litbang Departemen Agama RI, 2007), hal.165-166.
} 


\begin{tabular}{|c|c|c|c|c|c|}
\hline & & $\begin{array}{l}\text { - } \text { Ijtihad } \\
\text { istishlahi }\end{array}$ & & & tertentu \\
\hline 3 & MUI & $\begin{array}{l}\text { - } \text { Ijtihad jamai } \\
\text { - } \quad \text { Manhaji. }\end{array}$ & $\begin{array}{l}\text { - } \text { Tidak mengikuti } \\
\text { sistem yang jelas. } \\
\text { - mengikuti sistem } \\
\text { keputusan modern }\end{array}$ & $\begin{array}{ll}\text { - } & \text { Munas } \\
\text { - } & \text { Sidang Khusus }\end{array}$ & $\begin{array}{l}\text { Tidak mengikatkan } \\
\text { diri pada mazhab } \\
\text { tertentu }\end{array}$ \\
\hline 4 & $\begin{array}{l}\text { Dewan Hisbah } \\
\text { PERSIS }\end{array}$ & $\begin{array}{l}\text { - } \text { Merujuk pada } \\
\text { Alquran dan } \\
\text { Hadis Shahih } \\
\text { - } \text { Ijtihad Jamai } \\
\text { - Manhaji secara } \\
\text { samar }\end{array}$ & $\begin{array}{l}\text { Mengikuti sistem } \\
\text { surat keputusan } \\
\text { modern }\end{array}$ & $\begin{array}{ll}\text { - } & \text { Muktamar } \\
\text { - Sidang Khusus }\end{array}$ & $\begin{array}{l}\text { Tidak mengikatkan } \\
\text { diri pada mazhab } \\
\text { tertentu }\end{array}$ \\
\hline
\end{tabular}

\section{Kesimpulan}

Setelah mengkaji dan membandingkan berbagai segi empat lembaga fatwa di Indonesia, dapat disimpulkan beberapa hal sebagai berikut:

1. Bahwa ulama Indonesia berupaya responsif dan antisipatif menghadapi derasnya kemajuan IPTEK di berbagai bidang. Hal ini membuktikan adanya keinginan kuat ulama Indonesia untuk dapat memecahkan berbagai persoalan kekinian, mengatasi dan menjawab berbagai tantangan zaman. Di samping itu, secara ideal juga mengindikasikan adanya keinginan ulama agar setiap segi kehidupan insani, tidak melanggar norma-norma Islami.

2. Dilihat dari segi metodologi penetapan hukum oleh empat lembaga fatwa di Indonesia, ada tiga tipologi, yaitu:

a. Bahtsul Masail NU merujuk pada ketentuan hukum dalam kitab-kitab fikih (kutub mu'tabaraț) yang bermazhab Ahlussunnat wal Jamā'at, namun dalam praktiknya kitab - kitab mazhab Syāfi'i yang paling banyak digunakan. Caranya, men-tathbīq - kannya dengan nash-nash dalam kitab, merujuk 'ibārat dalam kitab-kitab fikih, jika tidak ditemukan maka dilakukan $i l \underline{h} \bar{a} q$, karena dianggap cukup kaya dan masih aktual untuk menjawab setiap isu yang berkembang. Hampir semua isu kontemporer dapat dicari jawabnya dengan metode tersebut.

b. Dengan semboyan kembali kepada Al - Quran dan Hadis, Majlis Tarjih dan Dewan Hisbah, berusaha menjawab segala persoalan termasuk isuisu kontemporer. Namun, ketika dihadapkan pada realitas, saat kesulitan 
menghadapi berbagai isu yang tidak tersurat maupun tersirat dalam nash, sebagai solusinya diaplikasikan metode yang dirumuskan oleh para mujtahid dan yang biasa digunakan oleh para mufti, digunakan metode komplementer, seperti Istiḥsān, mashlahat mursalat, sadd al-Dzarī'aț, dan sebagainya, termasuk karya-karya fikih masa lalu tidak dapat dihindari, namun tidak dinyatakannya secara terang-terangan.

c. MUI secara umum dapat dianggap sebagai perpaduan plus antara dua tipologi di atas, bersifat fleksibel dan dinamis, meskipun dalam dokumen sejumlah fatwa MUI tidak selalu menunjukkan tipe itu. Secara umum lembaga ini dalam menetapkan fatwa terlebih dulu mencari langsung dari teks Al - Quran dan Hadis, juga mengaplikasikan metode yang biasa digunakan oleh para mufti, qadli, atau mujtahid dengan menyebutkannya secara jelas, juga merujuk pada teks-teks kitab fikih. Al - Quran dan Hadis sebagai pedoman utama, pendapat fukaha masa lalu tetap dijadikan sebagai pertimbangan, dan metode rumusan para mujtahid juga digunakan.

3. Dilihat dari segi penggunaan metodologi penetapan hukum, empat lembaga fatwa di Indonesia secara praktis tidak terdapat perubahan tetapi mengalami dinamika. Secara idealis terlihat adanya keinginan untuk memperbaharui metodologi yang digunakan, misalnya pada Munas Bahtsul Masail di Bandar Lampung tahun 1992 telah ditetapkan, jika tidak dapat diselesaikan dengan metode qauli dan Ilhāa, maka dilakukan metode prosedur bermazhab secara manhaji. Demikian juga Majlis Tarjih, telah meluaskan cakupan ijtihad

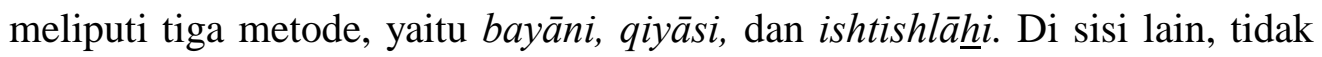
terdapat perbedaan prinsipil, semua lembaga tidak meninggalkan sumbersumber hukum atau metode pendukung lain yang menguatkannya, terlepas dari adanya kelaziman suatu lembaga fatwa menyebutkannya atau tidak, tetapi secara praktis diaplikasikan, semua mengacu pada sumber primer berdasarkan Al - Quran dan Sunnah, menggunakan sumber komplementer ijmak dan qiyas, juga menggunakan kaidah-kaidah suplementer seperti 
Istiḩsān atau konsep darurat, Sadd al-Dzarīaț, Mashlaḥat Mursalat, Istish $\underline{h} a b$, dan metode Qauli dan ilhāq.

\section{DAFTAR PUSTAKA}

Abdurrahman, Asymuni, Manhaj Tarjih Muhammadiyah, (Yogyakarta: Pustaka Pelajar, 2002).

Amien, Shiddiq (Ed.), Kumpulan Keputusan Dewan Hisbah Persatuan Islam, (Bandung: PERSIS, 2002)

Amin, M. Masyhur, $N U$ \& Ijtihad Politik Kenegaraannya, (Yogyakarta: Al-Amin Press, 1996).

Azhar, Muhammad, Posmodernisme Muhammadiyah, (Yogyakarta: Suara Muhammadiyah, 2005).

Djamil, Fathurrahman, Metode Ijtihad Majlis Tarjih Muhammadiyah, (Jakarta: Logos, 1995)

Hasaballāh, 'Ali, Ushūl al-Tasyri' al-Islāmi, (Mesir: Dār al-Ma'ārif, 1976).

Hassan, A. Soal Jawab Masalah Agama 1-2, (Bangil: CV. Pustaka Tamaam, 1985).

Ka'bah, Rifyal, Hukum Islam di Indonesia, Perspektif Muhammadiyah dan NU, (Jakarta: Universitas YARSI Jakarta, 1999).

Khaeruman, Badri, Pandangan Keagamaan Persatuan Islam, Sejarah, Pemikiran, dan Fatwa Ulamanya, (Bandung: Granada, 2005),

Lubis, Arbiyah, Pemikiran Muhammadiyyah dan Muhammad Abduh, Suatu Studi Perbandingan, (Jakarta: Bulan Bintang, 1993).

Masyhuri, A. Aziz, Masalah Keagamaan, (Surabaya: Dinamika Press, 1997).

Masyhuri, A. Aziz, Masalah Keagamaan Hasil Muktamar dan Munas Ulama Nahdlatul Ulama Kesatu 1926 s/d Keduapuluh Sembilan 1994.

Masyhuri, A. Aziz, Masalah Keagamaan, Hasil Muktamar dan Munas Ulama Nahdlatul Ulama Kesatu/1926 s/d Ketigapuluh/2000, (Depok: Qultum Media, 2004). 
Mudzhar, Muhammad Atho, Fatwa-fatwa Majlis Ulama Indonesia: Sebuah Studi tentang Pemikiran Hukum Islam di Indonesia,1975-1988 (Edisi Dwibahasa), (Jakarta dan Leiden: INIS., 1993).

Nasution, Harun, "Ijtihad Sumber Ketiga Ajaran Islam" dalam Jalaluddin Rahmat (ed.), Ijtihad dalam Sorotan, (Bandung: Mizan, 1996),

PBNU, Hasil-hasil Muktamar XXXI Nahdlatul Ulama, (Jakarta: PB NU, 2005).

PBNU, Keputusan Munas Alim Ulama \& Konbes Nahdlatul Ulama di Bandar Lampung 16-20 Rajab, 21 -25 Januari 1992, (Semarang: Sumber Barokah, 1992).

PP. Muhammadiyah Majlis Tarjih, Bayi Tabung dan Pencangkokan dalam Sorotan Hukum Islam, Keputusan Muktamar Tarjih Muhammadiyah ke-21 di Klaten Tahun 1980, (Yogyakarta: Penerbit Persatuan, 1980).

PP. Muhammadiyah Majlis Tarjih, Qaidah Lajnah Muhammadiyah, (Yogyakarta: PP. Muhammadiyah Majlis Tarjih, 1971).

PP. Muhammadiyah Majlis Tarjih, Tanya Jawab Agama 1,2,3, 4, (Yogyakarta: Suara Muhammadiyah, 2003).

PP. Muhammadiyah, Himpunan Putusan Majlis Tarjih Muhammadiyah, (tt.: PP. Majlis Tarjih Muhammadiyah, tth.).

PP. Muhammadiyah, Himpunan Qaidah/Peraturan Majlis Badan Lembaga Muhammadiyah. (tt: PP, Muhammadiyah, tth.).

PP. Persatuan Islam, Keputusan sidang Dewan Hisbah ke-3 dan ke-4 tentang Metodologi Pengambilan Keputusan Hukum Islam, dikeluarkan oleh PP. Persatuan Islam, Bandung pada 13 Shafar $1412 \mathrm{H}$.

Rahmat, M. Imdadun (Ed.), Kritik Nalar Fiqih NU., Transformasi Paradigma Bahtsul Masail, (Jakarta: Lakpesdam:, 2002).

Rosyada, Dede, Metode Kajian Hukum Dewas Hisbah Persis, (Jakarta: Logos, 1999).

Said, Imam Ghazali dan Asrori, A. Ma'ruf, Solusi Problematika Aktual Hukum Islam, Keputusan Muktamar, Munas, dan Konbes Nahdlatul Ulama (1926 M.-1999 M.), (Surabaya: Lajnah Ta'lif Wan Nasyr (LTN) Jawa Timur Bekerja Sama dengan Penerbit Diantara Surabaya, 2004). 
Sekretariat MUI, Himpunan Keputusan dan Fatwa Majlis Ulama Indonesia, (Jakarta: MUI, 1997).

Sekretariat MUI, Muqaddimah Pedoman Dasar Pedoman Rumah Tangga Pedoman Pentapan Fatwa, (Jakarta: MUI, 1986).

Sekretariat Persis, Qanun Asasi Persatuan Islam, (Bandung: PERSIS, 1968).

Syarafi, 'Abdul Majīd al-, Ijtihad Kolektif, (Jakarta: Pustaka Kautsar, 2002),

Wildan, Dadan, Sejarah Perjuangan PERSIS 1923-1963, (Bandung: Gema Syahida, 1995),

Zahro, Ahmad, Lajnah Bahtsul Masail 1926-1999: Tradisi Intelektual NU, (Yogyakarta: LkiS, 2002).

Zuhroni, Respon Ulama Indonesia terhadap Isu-isu Kedokteran dan Kesehatan Modern, (Jakarta: Litbang Departemen Agama RI, 2007).

PP. Persis 'Sejarah Persis' di http://www.PERSIS.or.id/site/modules.php?name= Content\&pa $=$ showpage\& pid $=5$. Diakses 2 Januari 2007.

Dewan Hisbah PP Persis tentang Hukum Donor Darah, Pemanfaatan Sel Punca, dan Hukum Bank ASI oleh PP Persatuan Islam, di http://www.persatuanislam. or.id/home.php?t=non berita\&arsip=fatwa. Diakses 18 Mei 2012.

PP. Persatuan Islam, "Metodologi dalam Menetapkan Hukum Islam" di http://www.persatuanislam.or.id/home.php?t=non_ berita\&arsip=fatwa. Diakses 18 Mei 2012. 